\title{
Working
}

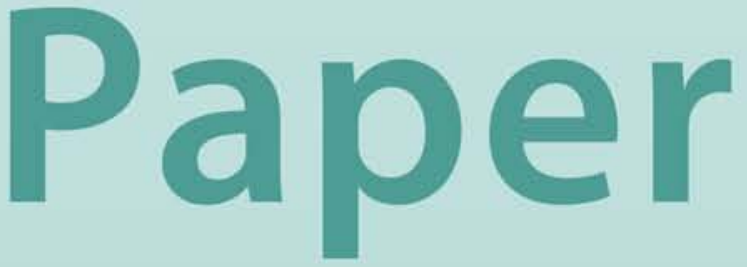


The Equilibrium Real Exchange Rate in a Commodity Exporting Country:

Algeria’s Experience

Taline Koranchelian 


\title{
IMF Working Paper
}

Middle East and Central Asia Department

\section{The Equilibrium Real Exchange Rate in a Commodity Exporting Country: Algeria's Experience}

\author{
Prepared by Taline Koranchelian ${ }^{1}$
}

Authorized for distribution by Erik De Vrijer

July 2005

\begin{abstract}
This Working Paper should not be reported as representing the views of the IMF. The views expressed in this Working Paper are those of the author(s) and do not necessarily represent those of the IMF or IMF policy. Working Papers describe research in progress by the author(s) and are published to elicit comments and to further debate.

Drawing on the existing literature, I estimate a long-run equilibrium real exchange rate path for Algeria. I find that the Balassa-Samuelson effect together with real oil prices explain the long-run evolution of the equilibrium real exchange rate in Algeria. The half-life of the deviation of the real exchange rate from the estimated equilibrium level is about nine months, similar to that in other commodity-exporting countries. The general conclusions are that: (i) there is a time-varying long-run equilibrium exchange rate in Algeria as in other commodity-exporting countries; and (ii) the real effective exchange rate of the Algerian dinar at end-2003 was broadly in line with this equilibrium.
\end{abstract}

JEL Classification Numbers: F31, F41

Keywords: Algeria, equilibrium real exchange rate Author(s) E-Mail Address: tkoranchelian@imf.org

${ }^{1}$ I would like to thank Paul Cashin, Jean Le Dem, and Gabriel Sensenbrenner for helpful comments and suggestions, and Fernanda Sayavedra for excellent research assistance. 
Contents

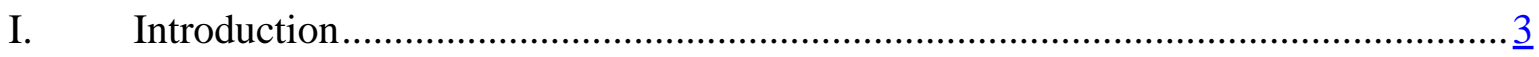

II. Developments in the Algerian Exchange Rate Regime ........................................

III. Review of the Literature ….....................................................................

IV. Determination of the Equilibrium Real Exchange Rate in Algeria ........................ $\underline{7}$

A. Purchasing Power Parity .......................................................................... 7

B. The Equibilibrium Real Exchange Rate and Fundamentals ........................... $\underline{8}$

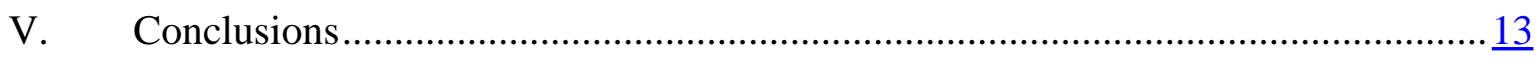

\section{Tables}

1. Tests of Order of Integration, January 1995-June 2004.....................................

2. Statistics for ADF (2) Unit Root Tests ....................................................... 10

3. Selected Results of the Vector Error Correction Model ..................................... 10

4. Vector Error Correction Tests........................................................................ 11

\section{Figures}

1. Real Effective Exchange Rate .....................................................................

2. Determinants of the Real Effective Exchange Rate, 1970-2003............................ $\underline{9}$

3. Actual and Equilibrium Real Effective Exchange Rate......................................12

4. Gap: Actual Minus Equilibrium Real Effective Exchange Rate ...........................12

Appendix

Theoretical Framework ........................................................................ 14

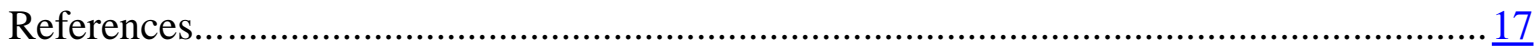




\section{INTRODUCTION}

\section{Attempts to model long-run movements in real exchange rates have generally had} mixed results. The simple purchasing power parity (PPP) hypothesis has proven to be a weak model of the long-run real exchange rate. ${ }^{2}$ The results of time-varying models that try to understand the relation between economic fundamentals and real exchange rate behavior have also been controversial, with many studies failing to find a robust relationship between the real exchange rate and its determinants. However, a recent study by Cashin, Céspedes, and Sahay (2002) developed a long-run equilibrium exchange rate model for commodityexporting countries and found that in many commodity-dependent low-income countries real commodity export prices and real exchange rates move together in the long run. Furthermore, Choudhri and Khan (2004) found that Balassa-Samuelson effects are relevant for developing countries and that the terms of trade also influence the real exchange rate.

This paper applies the Cashin et al. (2002) model to Algeria. Since 1995, the authorities have aimed at maintaining a stable real effective exchange rate (REER) against a basket of currencies weighted on the basis of the trade shares of Algeria's main trading partners. ${ }^{3}$ However, the REER has varied continuously over the last decade (Figure 1). ${ }^{4}$ Moreover, in 2002-03, the REER of the Algerian dinar depreciated by $17 \frac{1}{2}$ percent. The significant depreciation of the REER in 2002-03 raises two questions: (i) to what extent was the evolution of the

Figure 1. Real Effective Exchange Rate (1990=100) January 1995-September 2004

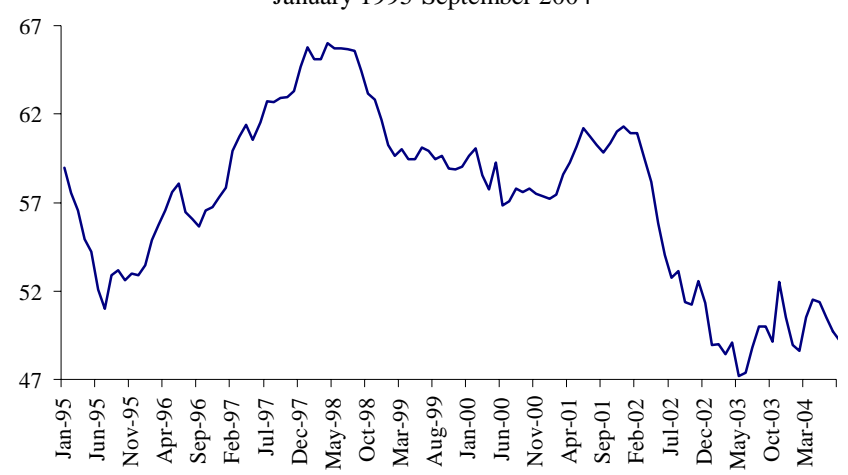
Algerian dinar in this period consistent with the equilibrium real exchange rate; and (ii) can economic fundamentals explain the exchange rate path in Algeria over the last decade?

This study finds evidence for the existence of a time-varying equilibrium real exchange rate in Algeria. The Balassa-Samuelson effect together with real oil prices (i.e., the terms of trade) explain the long-run equilibrium REER. Hence, Choudhri and Khan's (2004) conclusions are also applicable for the case of Algeria. The convergence speed towards

\footnotetext{
${ }^{2}$ A constant real exchange rate rule, based on the notion of purchasing power parity, aims at keeping the real exchange rate constant at a level that prevailed in some base period, when macroeconomic balance was thought to obtain, see Dornbusch (1982) and Montiel and Ostry (1991).

${ }^{3}$ Algeria's exchange rate regime is a managed float with no pre-announced path for the exchange rate. Algeria's main trading partners are: Austria, Belgium, Canada, China, France, Germany, Italy, Japan, the Netherlands, Spain, Switzerland, Sweden, Turkey, the United Kingdom, and the United States.

${ }^{4}$ An increase in the REER is equivalent to a real appreciation.
} 
equilibrium is about nine months, similar to the Cashin et al. (2002) findings for other commodity-exporting countries. The low productivity growth in the nonhydrocarbon sector has been the main factor behind the depreciation of the equilibrium real exchange rate over the last twenty years. Moreover, the analysis shows that the REER was close to its equilibrium level in 2002-03.

The remainder of the paper is organized as follows. After briefly describing the evolution of the Algerian exchange rate regime in Section II, Section III reviews the existing literature on the equilibrium real exchange rate. Section IV uses different models to determine the long-run equilibrium real exchange rate. First, it tests the PPP hypothesis. Then, it investigates the presence of a long-run cointegrating relationship between the real exchange rate and certain explanatory variables, estimates the speed at which the real exchange rate converges toward its equilibrium level, and assesses the gap between the actual and the equilibrium real exchange rate levels. Section V concludes.

\section{DeVelopments in the Algerian Exchange RATE REgime}

From January 1974, the exchange rate of the Algerian dinar was pegged to a basket of currencies - in which the U.S. dollar was assigned a relatively large weight due to its importance in hydrocarbon export receipts and debt-service payments-with adjustments taking place from time to time. The substantial appreciation of the U.S. dollar during the first half of the 1980s led to a strong rise in the real value of the Algerian dinar (of about 50 percent during 1980-85), thus undermining the competitiveness of the nonhydrocarbon sector and stimulating imports.

In 1986, Algeria's economy experienced the reverse oil shock, and the government responded to the dramatic erosion of export revenue by borrowing abroad and intensifying import restrictions. In parallel, the Bank of Algeria let the Algerian dinar depreciate against the basket by 31 percent between 1986 and 1988. Restrictions imposed on the allocation of foreign exchange increased demand for foreign exchange in the informal market, driving the parallel market premium to about 400 percent. This rigid system was replaced in 1988 by a system of foreign exchange allocation to the five public commercial banks within a framework of credit ceilings, which were consistent with balance of payments targets. The public banks in turn would allocate foreign exchange to their client public enterprises. Between 1989 and 1991, the Algerian dinar was again allowed to depreciate (more than 200 percent in nominal terms) to counteract the terms of trade losses during this period. In 1991, as part of an attempt to realign domestic relative prices and increase openness, the Bank of Algeria let the dinar depreciate by more than 100 percent to DA 22 per U.S. dollar. During 1991-94, the rate of nominal depreciation averaged 4 percent annually, bringing the value of the Algerian dinar to about DA 24 per U.S. dollar on the official market. This relative stability of the nominal rate did not correspond to economic fundamentals: adverse terms of trade shocks and expansionary fiscal and monetary policies resulted in inflation being persistently higher than in Algeria’s trading partners. The Algerian dinar, therefore, appreciated by 50 percent in real terms between October 1991 and end-1993. 
In 1994, the authorities put in place an adjustment program. One of the immediate objectives of the program was to correct the previous real appreciation of the Algerian dinar. Along with broad trade liberalization measures, including on trade-related payments, a twostep devaluation of the Algerian dinar (in total 70 percent) took place between April and September 1994. The spread between the parallel market and official exchange rates fell to about 100 percent during this time.

\section{Since 1995, Algeria's exchange rate policy has aimed at maintaining a stable real} exchange rate against a basket of currencies weighted according to the country's main trading partners and competitors. In 1995, the managed float regime was implemented through fixing sessions between the Bank of Algeria and commercial banks. An interbank foreign exchange market was established in 1996. Between 1995 and 1998 the REER appreciated by more than 20 percent, followed by a depreciation of 13 percent between 1998 and 2001. Following 16 months of real depreciation since early 2002, due to the appreciation of the euro against the U.S. dollar, the authorities intervened in the foreign exchange market in the second half of 2003 to realign the REER to its end-2002 level instead of its end-1995 level. Between June and December 2003, the Algerian dinar appreciated against the U.S. dollar by $11 \frac{1}{2} 2$ percent and the REER appreciated by $71 / 2$ percent.

The central bank strongly influences the nominal exchange rate on the official market. Through its intervention, the Bank of Algeria adjusts periodically the nominal exchange rate so as to achieve its real exchange rate target. In practice, the central bank holds the counterpart of most transactions on the foreign exchange market, as a result of the combination of three factors: (a) hydrocarbon exports account for more than 95 percent of total exports; (b) by law, the foreign exchange receipts from hydrocarbon exports have to be converted into dinars directly at the central bank; and (c) capital account transactions are subject to strict controls.

With the advent of the external convertibility of the dinar for current international transactions in 1997, the authorities have indicated that the parallel market has shrunk. The spread between the interbank market and the parallel market exchange rates was about 25 percent at end-2003.

\section{REVIEW OF THE LITERATURE}

PPP implies that the real exchange rate will revert to its mean, although it may deviate from its mean for several years at a time. ${ }^{5}$ The concept of PPP is often the first port of call for economists and market analysts who wish to estimate the equilibrium real exchange rate. The most widely used methodology to confirm or reject PPP is based on the analysis of the time series properties of the REER, which is assumed to measure changes in price level differences between a country and its trading partners (Rogoff, 1996). If the REER series is stationary and the speed of convergence of the REER towards its mean is fast enough, then

\footnotetext{
${ }^{5}$ See Dornbusch (1987).
} 
PPP can be considered to hold. Slow convergence is inconsistent with PPP, which only allows for short-term deviations from equilibrium.

PPP has proven to be a weak model of the long-run real exchange rate. Most studies have failed to find cointegrating relationships that are consistent with PPP (or, equivalently, consistent with a stationary real exchange rate). Meese and Rogoff (1983) demonstrated that a variety of linear structural exchange rate models failed to forecast more accurately than a random walk model for both real and nominal exchange rates. A well-known problem with PPP is that it fails to take into account that the equilibrium real exchange rate, defined as the price of tradable goods relative to nontradable goods that is consistent with both internal and external balance, is itself an endogenous variable that is likely to change over time in response to a variety of disturbances. Recent work has therefore emphasized the time-varying nature of the long-run real exchange rate. The equilibrium real exchange rate is not a single rate, but a path of real exchange rates over time that is affected by the current and expected values of variables that affect internal and external equilibrium. These variables are known as fundamentals. The multitude of potential fundamentals offered by researchers in their attempts to solve the PPP puzzle include the Balassa-Samuelson effect, ${ }^{6}$ government spending, cumulated current account imbalances, and real interest rate differentials as important drivers of long-run deviations from purchasing power parity (see Froot and Rogoff (1995) and Rogoff (1996)). Clark and MacDonald (2000) extended the approach to better differentiate between permanent and transitory components of the real exchange rate.

Several models have been developed to determine the equilibrium real exchange rate in developing countries. Edwards $(1989,1994)$ made a seminal attempt to build an equilibrium real exchange rate model specifically tailored to developing countries by exploring the longrun co-movements of the real exchange rate with variables such as the terms of trade, productivity, net foreign assets, the fiscal balance and measures of openness of the trade and exchange system. Khan and Ostry (1991) provided panel data estimates of the elasticity of the equilibrium real exchange rate with respect to terms of trade shocks and commercial policies in a static model.

The connection between economic fundamentals and exchange rate behavior has also been controversial. Many studies have failed to find a statistical link between real exchange rates and fundamentals. Edison and Melick (1999) failed to find cointegration between real exchange rates and real interest rate differentials, and Rogoff (1996) found a mixed empirical track record of the Balassa-Samuelson effect on real exchange rates. Recent efforts to confront these challenges have explored new approaches on both theoretical and empirical

\footnotetext{
${ }^{6}$ See Balassa (1964) and Samuelson (1964). The Balassa-Samuelson effect is described as follows: if a country experiences an increase in the productivity of the tradables sector (relative to its trading partners), its real exchange rate would tend to appreciate. For given prices of tradables, such stronger productivity would induce higher wages in the tradables sector; if wages are equalized across sectors, this would be reflected into higher prices of nontradables, and, hence an increase in the consumer price index relative to trading partners.
} 
fronts, including incorporating non-linearity in modeling exchange rate dynamics. ${ }^{7}$ Alternatively, it has also been recognized that if one could find a source of real shocks that is sufficiently volatile, one could potentially go a long way towards solving these major empirical exchange rate puzzles. In this respect, Chen and Rogoff (2002) found for four commodity-exporting developed countries that the dollar price of commodity exports exhibits a strong influence on real exchange rates. Similarly, Cashin et al. (2002) show that in many commodity-dependent low-income countries, the real price of commodity exports and real exchange rates move together in the long run. Furthermore, Choudhri and Khan (2004) found strong evidence of Balassa-Samuelson effects in developing countries.

\section{DETERmination OF THE EQUiLIBRIUM REAL EXCHANGE RATE IN Algeria}

\section{A. Purchasing Power Parity}

\section{PPP does not hold in Algeria, suggesting that the equilibrium real exchange rate may} vary over time. Figure 1 shows that the REER did not converge towards its mean between January 1995 and June 2004. Furthermore the augmented Dickey-Fuller (ADF) and PhillipsPerron test statistics show that the REER is non-stationary (Table 1). ${ }^{8}$ Finally, similarly to others' findings, 50 percent of a unit impulse (half-life speed (HLS)) dissipates in about 42 months or three and a half years, thus rejecting the hypothesis that deviations from PPP are short-lived. ${ }^{9}$ This result suggests that the equilibrium real exchange rate of the Algerian dinar may depend on fundamental variables.

Table 1. Tests of Order of Integration, January 1995- June 2004

\begin{tabular}{|c|c|c|c|c|}
\hline $\mathrm{ADF}$ & \multicolumn{2}{|c|}{ Level } & \multicolumn{2}{|c|}{ First Difference } \\
\hline & Lag & t-ADF & Lag & t-ADF \\
\hline LREER 1/ & 12 & -1.60 & 12 & $-2.93 *$ \\
\hline Phillips-Perron & \multicolumn{2}{|c|}{ Level } & \multicolumn{2}{|c|}{ First Difference } \\
\hline & Bandwith & $\mathrm{t}-\mathrm{PP}$ & Bandwith & $t-P P$ \\
\hline LREER 1/ & 6 & -1.18 & 6 & $-9.01 * *$ \\
\hline
\end{tabular}

* and ** denote rejection at 5 percent and 1 percent critical values.

$1 /$ LREER is the real effective exchange rate expressed in log.

\footnotetext{
${ }^{7}$ Examples of recent papers that explore non-linear exchange rate responses to deviations from economic fundamentals include Taylor and Peel (2000) and Taylor (2001).

8 The used data is the logarithm of the INS monthly REER for the period 1995:01-2004:06

${ }^{9}$ See Cashin et al., 2002; Chen and Rogoff, 2002. The estimated coefficient $\alpha$ of the AR(1) OLS regression is equal to 0.984 , thus the $\operatorname{HLS}=\operatorname{abs}(\log (1 / 2) / \log (\alpha))=42$ months.
} 


\section{B. The Equilibrium Real Exchange Rate and Fundamentals}

\section{Given that Algeria is a commodity exporting country, the model used is that developed by Cashin et al. (2002) for commodity-dependent countries (see Appendix). It is a} commodity price- and relative productivity-augmented PPP model. The REER is defined as a function of relative productivities between tradables and nontradables sectors, as well as the terms of trade:

where :

$$
E P / P^{*}=f\left(a_{x} / a_{i}^{*}, a_{n}^{*} / a_{n}, P_{x}^{*} / P_{i}^{*}\right)
$$

- $\quad E P / P^{*}=$ the real exchange rate defined as the domestic price of the domestic basket of consumption goods relative to the price of the foreign basket of consumption goods expressed in foreign currency;

- $\quad a_{x} / a_{i}^{*}=$ productivity differential between exports and import (foreign) sectors or between domestic and foreign tradables sectors;

- $\quad a_{n}^{*} / a_{n}=$ productivity differential between the foreign and domestic nontradables sectors; and

- $\quad P^{*}{ }_{\gamma} / P^{*}{ }_{i}=$ commodity terms of trade (or the price of the primary commodity with respect to the intermediate foreign good) measured in foreign prices.

The first two terms in equation (1) capture the Balassa-Samuelson effect-a productivity improvement in the tradables sector will tend to raise wages throughout the economy-which translates into a price increase in the nontradables sector, which, in turn, leads to an appreciation of the real exchange rate. The third term reflects the impact of the terms of trade. An increase in export prices leads to higher wages, and translates into an increase in non-tradable goods prices as well.

\section{The variables used in Algeria's model are the following:}

- $\quad$ LREER = the real effective exchange rate using INS data (2001=100), in logarithmic terms;

- $\quad$ LRGDPC = Real GDP per capita relative to trading partners. Normalized for each country to 1 in 2001, in logarithmic terms. Given the absence of data on unit labor costs, and, as often done in estimation of equilibrium exchange rates, this variable is used as a proxy for the productivity differentials (Balassa-Samuelson effect); and

- $\quad$ LROIL= real price of oil calculated, as in Cashin et al. (2002), by deflating the U.K. Brent spot price index by the manufactured exports unit price index for developed countries $(2001=100)$, in logarithmic terms. This is a proxy for the commodity terms of trade $\left(P^{*}{ }_{\gamma} / P^{*}\right)$.

The visual inspection of the movements in the three variables in Figure 2 suggests that movements in the REER largely reflect developments in Algeria's productivity relative to its trading partners (a deterioration over almost the entire period), and, to a lesser extent, changes in real oil prices. 
Figure 2. Determinants of the Real Effective Exchange Rate, 1970-2003

Real Effective Exchange Rate

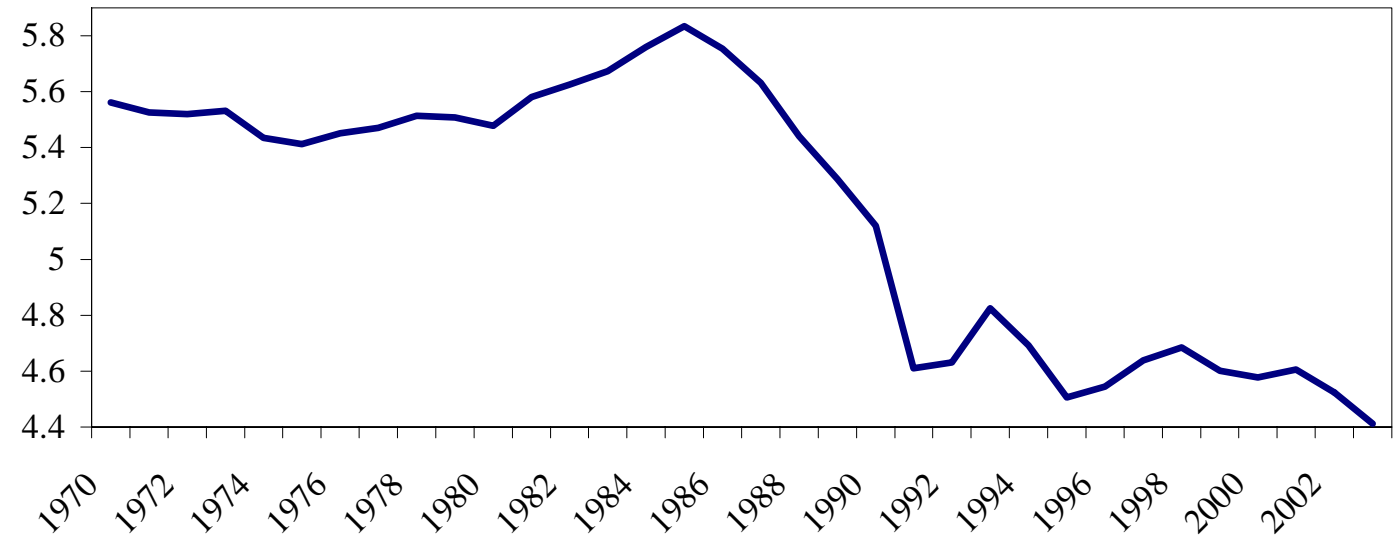

Real GDP per capita relative to trading partners

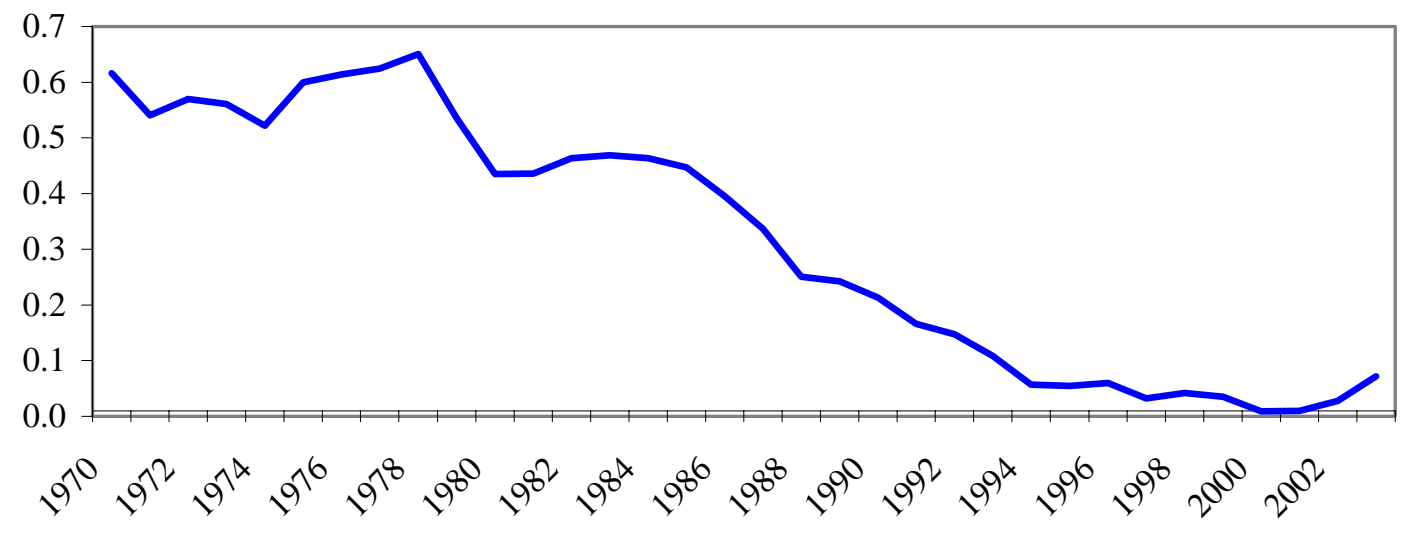

Real oil price

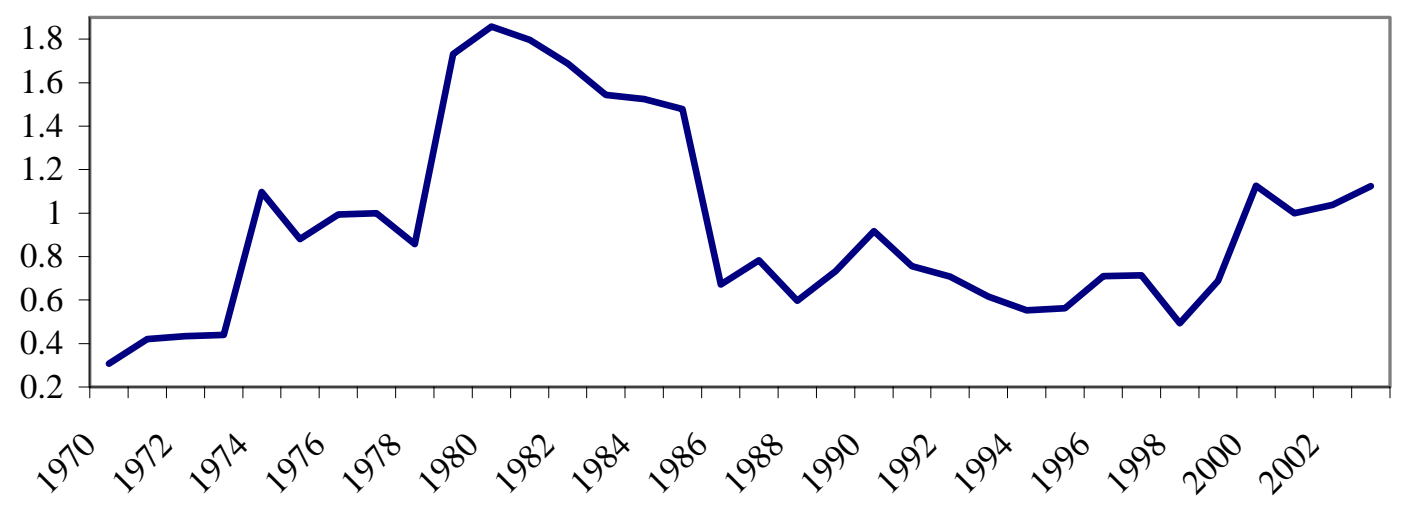


The dataset consists of annual data from 1970 to 2003. The ADF test indicates that the nonstationarity hypothesis cannot be rejected at the 5 percent confidence level in all three variables. However, for the first difference of the same variables, the hypothesis of nonstationarity is rejected at the 1 percent confidence level, suggesting that these variables are integrated of order one, I(1) (Table 2).

Table 2. Statistics for ADF(2) Unit Root Tests

\begin{tabular}{lcccc}
\hline \multicolumn{2}{c}{ Variables } & \multicolumn{2}{c}{ Level } & \multicolumn{2}{c}{ First Difference } \\
\hline & Lag & t-ADF & Lag & t-ADF \\
\cline { 2 - 5 } LREER & 9 & -0.08 & 9 & $-4.03 * *$ \\
LRGDPC & 9 & -0.84 & 9 & $-4.36 * *$ \\
LROIL & 9 & -2.67 & 9 & $-6.52 * *$ \\
\hline
\end{tabular}

Notes: Variables are as defined in the text. * and ${ }^{* *}$ denote rejection at 5 percent and 1 percent critical values.

The econometric analysis confirms the existence of a cointegration relationship between the REER, real oil prices, and Algeria's productivity differential relative to its trading partners. Table 3 shows the estimation of the vector error-correction model (VECM) using four lags for the changes in each variable (the lag structure is supported by appropriate tests). The Engle-Granger (1987) and Johansen (1995) maximum likelihood procedures are used to determine the number of cointegrating vectors among the variables. ${ }^{10}$ Both procedures indicate that there is at most one co-integrating vector (at the 5 percent confidence level). The coefficients of the cointegration vector are plausible, significant, and of the correct sign. The cointegration analysis is appropriate (all variables are nonstationary) and meaningful (not driven by the stationarity of one variable).

Table 3. Selected Results of the Vector Error Correction Model 1/

\begin{tabular}{|c|c|c|c|}
\hline \multicolumn{4}{|c|}{ Number of cointegrating vectors } \\
\hline \multicolumn{2}{|c|}{ Trace statistic } & \multicolumn{2}{|c|}{ Max Eigenvalue statistic } \\
\hline & $\begin{array}{l}\text { atistic } \\
1 \%\end{array}$ & \multicolumn{2}{|c|}{$5 \% \quad 1 \%$} \\
\hline 1 & 1 & \multicolumn{2}{|c|}{11} \\
\hline \multicolumn{4}{|c|}{ Estimates of the cointegrating relationship with the real exchange rate } \\
\hline LREER(-1) & LRGDPC(-1) & LROIL(-1) & $\mathrm{C}$ \\
\hline \multirow[t]{2}{*}{1} & -1.88 & -0.24 & -4.64 \\
\hline & {$[-16.42]$} & {$[-2.66]$} & \\
\hline \multicolumn{4}{|c|}{ Speed of adjustment of the real exchange rate } \\
\hline Cointeq1 & $\begin{array}{c}-0.60 \\
{[-3.87]}\end{array}$ & & \\
\hline \multicolumn{4}{|c|}{$\underline{\text { Half lifetime of the deviation from equilibrium exchange rate }}$} \\
\hline in years & 0.75 & in months & 9 \\
\hline
\end{tabular}

1/ Numbers in [ ] are t-statistics.

\footnotetext{
10 These procedures will provide better results for larger numbers of observations.
} 
Furthermore, the exclusion test suggests that none of the variables can be excluded from the long-run relationship (Table 4). The hypothesis that the residuals have a normal distribution is rejected due to excess kurtosis. The lag structure appears to be correct: if a fifth lag is introduced, the tests accept the hypothesis that the additional lag is jointly insignificant across equations.

Table 4. Vector Error Correction Tests

\begin{tabular}{|c|c|c|c|c|}
\hline \multicolumn{5}{|c|}{ Exclusion test 1/ } \\
\hline LREER & LRGDPC & LROIL & CHI-SQ & \\
\hline 21.89 & 21.93 & 16.34 & 3.94 & \\
\hline \multicolumn{5}{|c|}{ Normality test } \\
\hline & \multicolumn{2}{|c|}{$\underline{\mathrm{df}}$} & \multicolumn{2}{|l|}{ Probability } \\
\hline Skeweness & \multicolumn{2}{|c|}{3} & \multicolumn{2}{|l|}{0.74} \\
\hline Kurtosis & \multicolumn{2}{|c|}{3} & \multicolumn{2}{|l|}{0.00} \\
\hline Jarque-Bera & \multicolumn{2}{|c|}{3} & \multicolumn{2}{|l|}{0.00} \\
\hline \multicolumn{5}{|c|}{$\begin{array}{l}\text { VEC Lag Exclusion Wald Tests 2/ } \\
\text { (Chi-squared test statistics) }\end{array}$} \\
\hline DLag 1 & DLag 2 & DLag 3 & DLag 4 & $\mathrm{df}$ \\
\hline 37.7 & 34.7 & 22.1 & 32.2 & 9 \\
\hline$[0.00]$ & {$[0.00]$} & {$[0.00]$} & {$[0.00]$} & \\
\hline
\end{tabular}

The estimated long-run real exchange rate equilibrium equation takes the following form:

$$
\begin{aligned}
& \text { LREER = } 4.64 \text { + 1.88 LRGDPC + 0.24 LROIL } \\
& \text { (0.11) (0.08) } \\
& \text { [16.42] [2.66] }
\end{aligned}
$$

- $\quad$ An increase in real GDP per capita relative to trading partner countries of 1 percent is associated with an appreciation of the REER of almost 2 percent.

- An increase in real oil prices of 1 percent is associated with an appreciation of the REER of about 0.2 percent.

Whenever the real exchange rate deviates from its equilibrium level due to a specific shock, it reverts to its equilibrium level fairly quickly in the absence of further shocks. Depending on the cause of the gap, the adjustment requires that the real exchange rate either moves progressively toward a new equilibrium level, or returns from its temporary deviation to the initial equilibrium value. The parameter of the cointegration vector of 0.6 implies that 
the half-life speed (HLS) of dissipation of a unit impulse is 0.75 years. ${ }^{11}$ In other words, the model estimates that 50 percent of such a gap would be eliminated within nine months. This adjustment speed is comparable to the eight months found by Cashin et al. (2002), and much shorter than Rogoff's (1996) estimate of three to five years.

\section{Figures 3 and 4 show that there are no current signs of misalignment of the Algerian dinar. $^{12}$ The actual REER appears to} have been close to its estimated equilibrium in 2002-03. Following the appreciation of the euro against the U.S. dollar in 2002-03, the gap between the actual and the smoothed equilibrium REER declined from +9 percent in 2001 to +2 percent in 2002 and to -6 percent on average in 2003. This depreciation was a little more than what was required by the fundamentals. However, the correction made by the authorities in the second half of 2003 (by appreciating the Figure 3. Actual and Equilibrium Real Effective Exchange Rate nominal exchange rate) brought the REER back to close to its equilibrium. level. By year-end, the REER was 3 percent higher than its annual average level. ${ }^{13}$ Figure 3 also shows the 1986-88 depreciation in response to the reverse oil shock, which brought the 1985 overvalued exchange rate back to its equilibrium.

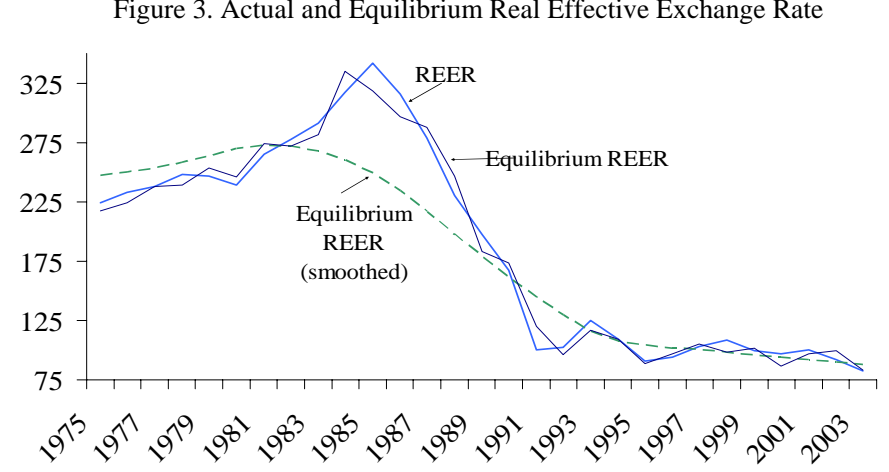

Figure 4. Gap: Actual Minus Equilibrium Real Effective Exchange Rate (in percent of equilibrium level)

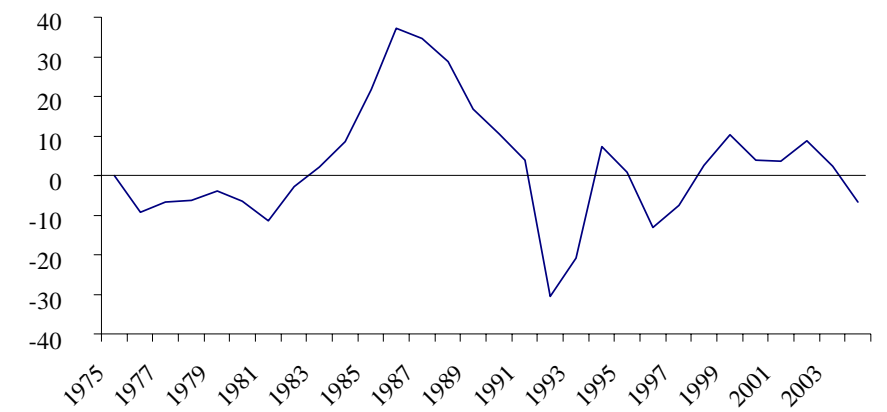

${ }^{11}$ The implied half-life of the shock to commodity-price- and productivity-augmented PPP is calculated as follows: the time ( $\mathrm{T}$ ) required to dissipate $\mathrm{x}$ percent (in this case, 50 percent) of a shock is determined according to $(1-\Theta)^{\mathrm{T}}=(1-\mathrm{x})$, where $\Theta$ is the coefficient of the error-correction term and $\mathrm{T}$ is the required number of periods (years).

${ }^{12}$ The smoothed equilibrium real exchange rate in Figure 3 is derived by applying to the explanatory variables a Hodrick-Prescott filter with a smoothing factor of 100 . This smoothing technique neutralizes the impact of temporary fluctuations in explanatory variables on the evolution of the equilibrium real exchange rate by deriving a proxy for the long run equilibrium values of these variables. This measure can therefore be defined as the level of the REER that is consistent in the long run with the equilibrium values of the explanatory variables.

\footnotetext{
13 The small gap between the equilibrium and the actual level of the REER at end-2003 could be due to temporary shocks not captured by the long-run equilibrium model. In addition, the assessment of the equilibrium level using the Hodrick-Prescott filter is not very accurate for end-point data.
} 


\section{CONCLUSIONS}

\section{Drawing on the existing literature, this study estimates a long-run equilibrium real exchange rate path for Algeria.}

The main conclusion is that REER movements in Algeria can be explained by fundamental variables. The long-run real exchange rate of Algeria is time-varying, and dependent on movements in relative productivity and real oil prices in line with Cashin et al. (2002). Deviations of the real exchange rate from its equilibrium level are adjusted fairly rapidly (HLS=9 months), confirming that Balassa-Samuelson- and commodity-priceaugmented PPP determines the real exchange rate in Algeria.

Furthermore, the analysis shows that the REER was not misaligned in 2002-03. Modelderived estimates of the long-run equilibrium real exchange rate replicate most recognized periods of currency overvaluation in Algeria. The estimates support the conclusion that the 2002-03 depreciation of the REER followed by an appreciation in the second half of 2003 were consistent with developments in its fundamental determinants.

The results of this study have important implications for Algeria's exchange rate policy. Although Algeria should continue with a managed float, targeting a constant REER over a prolonged period is not warranted as such a policy does not accommodate real shocks by allowing the nominal exchange rate and/or relative prices to move. Exchange rate policy should be directed to align the real exchange rate with its fundamental determinants, namely relative productivity and real oil prices. 


\section{Theoretical Framework ${ }^{14}$}

The model is based on a small open economy that produces two different types of goods: a nontradable good and an exportable good. The production of this exportable good is associated with the production of a primary commodity. Factors are mobile and both goods are produced domestically.

\section{A. Domestic production}

There are two different sectors in the domestic economy: one sector produces an exportable called "primary commodity"; the other sector consists of a continuum of firms producing a nontradable good. For simplicity, it is assumed that the production of these two different types of goods requires labor as the only factor. The production functions are:

Primary commodity sector: $\quad Y_{x}=a_{x} \cdot L_{x}$

Nontradable good sector: $\quad Y_{n}=a_{n} . L_{n}$

Where $x$ represents the primary commodity sector, $n$ the nontradable good sector, $L$ the amount of the labor input demanded by each sector, and $a$, the productivity of labor in each sector. The model assumes that labor can move freely across sectors in such a way that the labor wage $w$ must be the same across sectors. The price equations are as follows:

$$
P_{x}=w / a_{x} \quad \text { and } \quad P_{n}=w / a_{n}
$$

In equilibrium, the marginal productivity of labor must equal the real wage in each sector. It is assumed that the price of the primary commodity is exogenous, and that there is perfect competition in the nontradables sector. These assumptions yield:

$$
P_{n}=a_{x} / a_{n} \cdot P_{x}
$$

Thus, the relative price of the nontradable good $P_{n}$ with respect to the primary commodity $P_{x}$ is completely determined by technological factors and is independent of demand conditions.

\section{B. Domestic Consumers}

The economy is inhabited by a continuum of identical individuals that supply labor inelastically (with $L=L_{x}+L_{n}$ ) and consume a nontradable good and a tradable good. This tradable good is imported from the rest of the world and is not produced domestically. The assumptions on preferences imply that the primary commodity is also not consumed domestically. Each individual chooses the consumption of the nontradable and tradable good

\footnotetext{
${ }^{14}$ Cashin et al (2002).
} 
to maximize utility, which is assumed to be increasing in the level of aggregate consumption given by:

$$
C=\kappa \cdot C_{n}^{\gamma} \cdot C_{t}^{1-\gamma}
$$

where $C_{n}$ represents purchases of the nontradable good, $C_{t}$ purchases of the imported good and $\kappa=1 /\left[\gamma^{\gamma}(1-\gamma)^{(1-\gamma)}\right]$ is a constant. The minimum cost of one unit of consumption $C$ is given by:

$$
P=\left(P_{n}\right)^{\gamma} \cdot\left(P_{t}\right)^{1-\gamma}
$$

Where $P_{t}$ is the price in local currency of one unit of the tradable good. As usual, $P$ is defined as the consumer price index. Now, the law of one price is assumed to hold for the imported good:

$$
P_{t}=P^{*} / E
$$

Where $E$ is the nominal exchange rate, defined as the amount of foreign currency per local currency, and $P^{*}{ }_{t}$ is the price of the tradable (imported) good in terms of foreign currency.

\section{Foreign Production and Consumption}

So far it was assumed that the primary commodity is not consumed by domestic agents and is therefore completely exported. In addition, the domestic economy also imports a good that is produced only by foreign firms. ${ }^{15}$ The foreign region consists of three different sectors: a nontradable sector; an intermediate sector; and a final goods sector. The nontradable sector produces a good that is consumed only by foreigners using labor as the only factor. The technology available for the production of this good is given by:

$$
Y_{n}^{*}=a_{n}^{*} \cdot L_{n}^{*}
$$

The foreign economy also produces an intermediate good that is used in the production of the final good. This intermediate good is produced using labor as the only factor. In particular, the production function available to firms in this sector is represented by:

$$
Y_{i}^{*}=a_{i}^{*} \cdot L_{i}^{*}
$$

Labor mobility across (foreign) sectors ensures that the foreign wage is equated across sectors. ${ }^{16}$ The price of the foreign nontradable good as a function of relative productivities and the price of the foreign intermediate good is:

\footnotetext{
${ }^{15}$ The foreign economy is different from the rest of the world. The latter also includes other countries producing the primary commodity.

${ }^{16}$ It is assumed that labor can freely move across sectors within each region (domestic and foreign) but cannot move across regions.
} 


$$
P_{n}^{*}=a_{i}^{*} / a_{n}^{*} \cdot P_{i}^{*}
$$

The production of the final good involves two intermediate inputs. The first is the primary commodity (produced by several countries, among them the domestic economy). The second is an intermediate good produced in the rest of the world. Producers of this final good, also called the tradable good, produce it by assembling the foreign intermediate input $Y_{i}^{*}$ and the foreign primary commodity $Y_{x}^{*}$ through the following technology:

$$
Y_{t}^{*}=v \cdot\left(Y_{i}^{*}\right)^{\beta} \cdot\left(Y_{x}^{*}\right)^{1-\beta}
$$

Now, it is straightforward to show that the cost of one unit of the tradable good in terms of the foreign currency is given by:

$$
P_{t}^{*}=\left(P_{i}^{*}\right)^{\beta} \cdot\left(P_{x}^{*}\right)^{1-\beta}
$$

Foreign consumers are assumed to consume the foreign nontradable good and this final good in the same fashion as domestic consumers. They also supply labor inelastically to the different sectors. Therefore, the consumer price index for the foreign economy can be represented by:

$$
P^{*}=\left(P^{*}\right)^{\gamma} \cdot\left(P^{*}\right)^{1-\gamma}
$$

The real exchange rate in the domestic economy is determined by equations (6) and (13):

$$
E P / P^{*}=\left(a_{x} / a_{i}^{*} \cdot a_{n}^{*} / a_{n} \cdot P_{x}^{*} / P_{i}^{*}\right)^{\gamma}
$$




\section{References}

Balassa, B., 1964, “The Purchasing-Power Parity Doctrine: A Reappraisal,” Journal of Political Economy, Vol. 72.

Cashin, P., L. Céspedes, and R. Sahay, 2002, "Keynes, Cocoa, and Copper: In Search of Commodity Currencies,” IMF Working Paper 02/223 (Washington: International Monetary Fund).

Chen, Y. and K. Rogoff, 2002, “Commodity Currencies and Empirical Exchange Rate Puzzles,” IMF Working Paper 02/27 (Washington: International Monetary Fund).

Clark, P., and R. MacDonald, 2000, "Filtering the BEER: A Permanent and Transitory Decomposition,” IMF Working Paper 00/144 (Washington: International Monetary Fund).

Choudhri, E. U. and M. S. Khan, 2004, "Real Exchange Rates in Developing Countries: Are Balassa-Samuelson Effects Present?” IMF Working Paper 04/188 (Washington: International Monetary Fund).

Dickey, D. and W. Fuller, 1981, "Likelihood Ratio Statistics for Autoregressive Time Series with a Unit Root,” Econometrica, Vol. 49.

Dornbusch, R., 1982, “PPP Exchange-Rate Rules and Macroeconomic Stability,” Journal of Political Economy, Vol. 90. No. 1.

_ 1987, "Purchasing Power Parity,” in The New Palgrave: A Dictionary of Economics, edited by John Eatwell, Murray Milgate, and Peter Newman (London: MacMillan; New York: Stockton Press).

Edison, H. and W. Melick, 1999, “Alternative Approaches to Real Exchange Rates and Real Interest Rates: Three Up and Three Down,” International Journal of Finance and Economics, Vol. 4.

Edwards, S., 1989, Real Exchange Rates, Devaluation and Adjustment: Exchange Rate Policies in Developing Countries (Cambridge, Massachusetts: MIT Press).

_, 1994 , "Real and Monetary Determinants of Real Exchange Rate Behavior: Theory and Evidence from Developing Countries,” in Estimating Equilibrium Exchange Rates, edited by J. Williamson (Washington: Institute for International Economics).

Engle, R. F and C. Granger, 1987, “Co-integration and Error Correction: Representation, Estimation and Testing,” Econometrica, Vol. 55. 
Froot, K. and K. Rogoff, 1995, “Empirical Research on Nominal Exchange Rates,” in Handbook of International Economics, Vol. 3, edited by G. Grossman, and K. Rogoff (Amsterdam: Elsevier).

International Monetary Fund, 1998, “Algeria: Stabilization and Transition to the Market,” IMF Occasional Paper No. 165 (Washington: International Monetary Fund).

Johansen, S., 1995, Likelihood-based Inference in Cointegrated Vector Autoregressive Models (Oxford: Oxford University Press).

Khan, M. S. and J. Ostry, 1991, "Response of the Equilibrium Real Exchange Rate to Real Disturbances in Developing Countries,” IMF Working Paper 91/3 (Washington: International Monetary Fund).

Meese, R., and K. Rogoff, 1983, "Empirical Exchange Rate Models of the Seventies: Do They Fit Out of Sample?” Journal of International Economics, Vol. 14.

Montiel, P. and J. Ostry, 1991, "Macroeconomic Implications of Real Exchange Rate Targeting in Developing Countries,” Staff Papers, Vol. 38, No. 4 (Washington: International Monetary Fund).

Rogoff, K., 1996, “The Purchasing Power Parity Puzzle,” Journal of Economic Literature, Vol. 34.

Samuelson, P., 1964, “Theoretical Notes and Trade Problems," Review of Economics and Statistics, Vol. 46 (May).

Taylor, A., 2001, "Potential Pitfalls for the Purchasing Power Parity Puzzle? Sampling and Specification Biases in Mean-Reversion Tests of the Law of One Price," Econometrica, Vol. 69, No. 2.

Taylor, M. and D. Peel, 2000, “Nonlinear Adjustment, Long Run Equilibrium and Exchange Rate Fundamentals,” Journal of International Money and Finance, Vol. 19, No. 1. 